\title{
Város és nagyvállalat együttmüködése hírnevük alakításában: Győr és az Audi Hungaria Zrt.
}

\author{
City and a company cooperation in reputation \\ management: Györ city and the Audi Hungaria
}

\author{
JAKAB PETRA, KONCZOSNÉ SZOMBATHELYI MÁRTA
}

JAKAB Petra: doktorjelölt, Széchenyi István Egyetem, Regionális- és Gazdaságtudományi Doktori Iskola; idegenforgalmi referens, Győr Megyei Jogú Város Polgármesteri Hivatala; 9021 Győr, Városház tér 1.; jakab.petra@gyor-ph.hu; https://orcid.org/0000-0003-2228-4211 KONCZOSNÉ SZOMBATHELYI Márta: egyetemi docens, Széchenyi István Egyetem, Vezetéstudományi és Szervezeti Kommunikáció Tanszék; 9026 Győr, Egyetem tér 1.; kszm@sze.hu; https://orcid.org/0000-0001-5248-7752

KULCSSZAVAK: PR; városmarketing; hírnévmenedzsment; szervezeti kommunikáció

ABSZTRAKT: Ahogy a fogyasztási javak piacán versenyfutás zajlik a fogyasztókért, úgy versenyeznek a harmadik évezred városai a lakosokért, a befektetőkért, a nagyvállalatokért, a turistákért. E versenyfutásban nagy fegyvertény a város imázsa, jó hírneve, reputációja, ezek tudatos alakítása. Győr, a dinamikusan fejlődő város gazdasága többszöri modellváltás után az autóiparra épül, fő pillére a városban telephelyet alapító, jelentős nemzetközi nagyvállalat, az Audi Hungaria Zrt.

A kutatás célja, hogy a PR, a városmarketing, a városi és vállalati hírnévkutatás közös metszeteként új aspektusban világítson rá a közös térben levő gazdasági és önkormányzati szektor még hatékonyabb együttműködési lehetőségeire.

A tanulmányból a vállalat és város hírnévépítési folyamatáról, ezek közös mozzanatairól adunk képet, amely - az elméleten túl - a gyakorlatban is hasznosítható információkat nyújt. A hírnévelemek, a hírnév alakításának folyamatvizsgálata során azt mutatjuk be, hogyan tud együttműködésük során egy nagyvállalat és a neki otthont adó város hírnevük stratégiai alakításában szinergiákat felmutatni, ezáltal a területi tőkét erősíteni.

Petra JAKAB: PhD student, Doctoral School of Regional and Economic Sciences, Széchenyi István University; tourism consultant, City Hall of Györ; Városház tér 1., H-9021 Győr, Hungary; jakab.petra@gyor-ph.hu; https://orcid.org/0000-0003-2228-4211

Márta KONCZOSNÉ SZOMBATHELYI: associate professor, Department of Leadership and Organisational Communication, Széchenyi István University; Egyetem tér 1., H-9026 Győr, Hungary; kszm@sze.hu; https://orcid.org/0000-0001-5248-7752

KEYWORDS: PR; city-marketing; reputation management; corporate communication

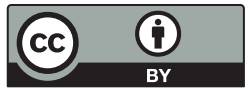


ABSTRACT: Because on the market of the consumer goods there is a race for customers, 21stcentury cities compete for inhabitants, tourists, investors and international companies. In this competition, a huge scale of city marketing tools is available from among which the city's image and good reputation and its conscious framing are one of the most important ones.

The economy of the dynamically developing Györ experienced several system changes: it had transformed from a commercial city into an industrial one and, nowadays, it has been transformed into a dynamically developing center. Today Györ is the sixth biggest city in Hungary, home of more than 130 thousand inhabitants. It is the center of the Kisalföld region, the county seat of Gyorr-Moson-Sopron County. It is an episcopal seat, a city rich with history. It is the third richest city of monuments in Hungary, home of the Champions League winner women handball team of Györi Audi ETO KC and also a university city. These are undoubted facts about it, which, in the second decade of the 2000s, are declared by the slogan "Future is being built in Györ!".

The city's economy is based - after several model changes - on the car manufacturing industry. Its main leg is the Audi Hungaria Zrt., and other important contributors are the suppliers connecting organically to it. Therefore, no wonder that economic prosperity has their mark not only in economic indices but also in the city's image and in the identity of inhabitants. The blooming economical background has its positive effects on the near zero unemployment rates and on fully booked accommodation facilities. On the other hand, it also needs new, qualified workforce, and on weekends and in periods with lower business intensity it could serve more leisure tourists. In attracting young, high-educated inhabitants, Audi Hungaria's reputation serves the city's needs. But, are there any tourists willing to visit a destination with a strong industrial reputation? In order to attract leisure tourists, how should the city balance being Hungary's third richest settlement on monuments and being the Hungarian citadel of car manufacturing?

Nowadays in Hungary, there are more and more cities focusing on managing their reputation, but we cannot find another city like Györ, who is working so closely with their stakeholders in order to build and maintain its positive outlook.

\section{Bevezetés}

Győr, a dinamikusan fejlődő város gazdasága többszöri modellváltás után az autóiparra épül, ennek fó pillére a városban letelepedett nemzetközi nagyvállalata, az Audi Hungaria Zrt., jelentős támpillérei pedig a hozzá szervesen kapcsolódó beszállító cégek. Így nem csoda, ha a város jelene, a gazdasági prosperitás nemcsak gazdasági mutatószámokban, hanem a város arculatában, lakosainak identitásában is intenzíven jelen van (Jakab 2014, 2016a, 2016b).

A tanulmány célja, hogy a PR, a városmarketing, a városi és vállalati hírnévkutatás közös metszeteként egy mások által még nem kutatott aspektusban világítson rá a gazdasági szféra és az önkormányzati szektor még hatékonyabb együttműködési lehetőségeire. A hírnévelemek, a hírnév alakításának folyamatvizsgálata eredményeképp feltárjuk, hogyan tud együttműködésük során egy nagyvállalat és a neki otthont adó város hírnevük stratégiai alakításában szinergiákat felmutatni, ezáltal a területi tőkét erősíteni. A 2011 óta érvényben lévő marketingkommunikációs együttműködés, „A jövő Győrben épül!” intézményesülését, annak hatását vizsgáljuk. 


\section{Elméleti háttér}

Míg a városokban leginkább városmarketing-tevékenységről vagy desztinációmenedzsmentről beszélünk, amikor egy adott település népszerüsítéséről van szó, addig a vállalatokban a PR tudományterületéhez tartozó hírnévépítési tevékenység figyelhető meg - főként ott, ahol nem egy adott termék, hanem egy konkrét vállalat márkázásán, népszerűsítésén dolgoznak a szakemberek. Fontos tisztáznunk ezért a két tudományterület, a marketing és a PR viszonyát (Kotler, Mindak 1991), bővebben kitérve a városmarketingre és a hírnévépítésre.

Az 1980-as évekig a marketing és a public relations céljainak és tevékenységének különbözőségét vallották: a marketing alapvetően a piaccal, míg a PR egy szervezet nyilvánosságával, közönségével foglalkozott, a fogyasztók és az ügyfelek kivételével. Az 1980-as évektől kezdve, a reklámköltségek emelkedése miatt a vállalatok a reklámozás alternatív formáit keresve, az eladások növelése érdekében a fogyasztói és márkahűség kialakításának lehetőségeit kezdték feltárni. A marketing public relations (MPR) eszközeit használva az új termékek és szolgáltatások piacra vitelekor a híreknek és eseményeknek egyre nagyobb publicitást generáltak, azaz a public relations eszközeit használták marketingcélokra. Az MPR különbözik a szervezeten belüli public relations tevékenységtől. A CPR, azaz a corporate public relations (szervezeti PR) a szervezet stakeholdereivel (alkalmazottak, befektetők, kormányzat, média stb.) való kommunikációt

1. ábra: A marketing és a public relations funkciói és ezek átfedései

Functions of marketing and public relations and their overlapping areas

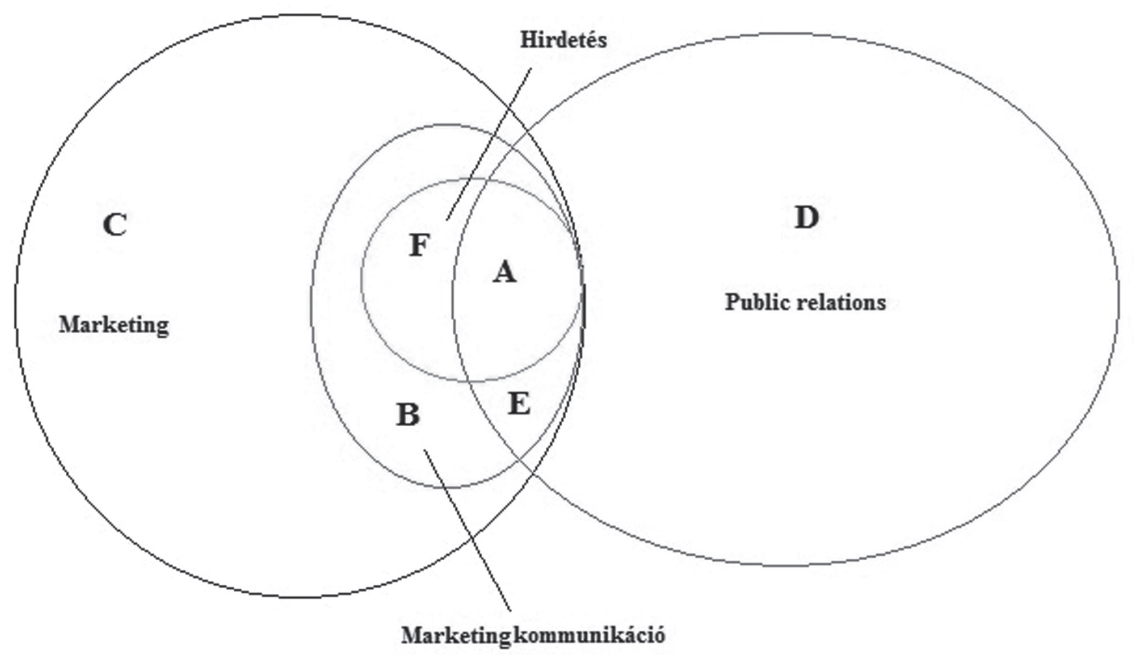

A jelölések értelmezése: A: szervezeti hirdetési tevékenység; B: direkt marketing és eladásösztönzés; C: disztribúció; D: CPR, azaz a szervezeti public relations; E: marketing public relations; F: tömegmédia-hirdetések. Forrás: Cornelissen 2011, 20. 
jelenti. Az 1. ábra a marketing és PR tevékenységeit szemlélteti, rávilágítva a két terület közös funkcióira, valamint a CPR és MPR közötti különbségekre.

\section{Városmarketing}

A városmarketing a harmadik évezred városainak versenye a lakosokért, befektetőkért, hazai és nemzetközi nagyvállalatokért, turistákért. Tartalmát tekintve olyan tevékenység, mely a város piaci pozicionálásán túl a különböző igénycsoportok érdekeinek felmérését, az igényeiknek megfelelő cselekvési terv felállítását és végrehajtását jelenti. Célja a polgároknak, a régió lakóinak, az ide látogatóknak (turisták) és a gazdasági szektor szereplőinek (befektetők) az elégedettsége, melyek elérésére különböző eszközök állnak rendelkezésre.

A városmarketing fogalmát kutatásunk szempontjából Enyedi György $(1995,2$.$) megfogalmazásában találtuk a legátfogóbbnak: „A városmarketing a$ gazdaság bővülését szolgáló várospolitikai dimenzió egyik legfontosabb és a marketing szempontjából egy sajátos eszköze, hiszen a város egy sajátos áru, egyidejűleg adjuk el számos vásárlónak, a vonzásra kiszemelt célcsoportoknak, különböző célokra, ám mégsem kerül más tulajdonába. Számukra szükséges megjeleníteni a város arculatát. Többnyire gazdasági telephelyet kínálunk, de egyúttal a hely történelmét is, a helyhez kapcsolódó értékeket és érzelmeket, a helyi társadalmat is, szokásaival és kultúrájával."

Az adott hely versenyképességét vonzerejének termékké alakítása és márkázása teremti meg. Mindennek kulcsa a desztináció kommunikációja, hiszen a helyzetnek és alkalomnak megfelelő hangsúlyokkal, a célcsoportnak megfelelő üzenetekkel jelentős mértékben elősegíthetjük, hogy a desztináció mint márka egyre népszerübb és keresettebb legyen (Piskóti 2012; Piskóti et al. 2002).

\section{A hírnév és épitöelemei}

A PR fejlődésével - főként a vállalati termékverseny kiéleződése miatt - felértékelődött a hírnév menedzselése, az elmúlt évtizedekben számos külföldi és hazai szakember foglalkozott vele (Konczosné Szombathelyi 2013a, 2013b, 2013c).

A hírnév mint fogalom mind a hazai, mind a nemzetközi szakirodalomban egyértelműen a public relations területéhez kötődik. Az angol reputation jelentéséből egyszerüen reputációnak is fordított fogalomnak számos definíciója létezik (Whetten 1997). Fombrun (1996) definíciója jól összegzi a vállalati hírnév különböző értelmezéseit. Eszerint a vállalati hírnév a cég múltbeli tevékenységének és eredményeinek kollektív reprezentációja, amely leírja a cég azon képességét, hogy értékes eredményt adjon a stakeholdereinek. Azt méri, hogy milyen a cég relatív megítélése egyrészt a belső (munkatársak), másrészt a külső (stakeholderek) viszonylatban. Olyan általános elképzelés, amelyet egy cég- 
ről stakeholderei, érdekcsoportjai vélnek, továbbá annak észlelése, hogy egy vállalat képességei mennyire tudnak találkozni stakeholdereinek az elvárásaival. A vállalat hírnevét általános becslésként definiáljuk, amelyet a vállalat összetevői eredményeznek, azaz a vállalat nevére való tisztán affektív (indulati) vagy emocionális reakciók (Fombrun 1996, 37.).

A hírnév vizsgálatához fontos látnunk, hogyan épül fel. Roper és Fill (2012) a hírnév létrejöttének folyamatában a hírnév építőköveinek az identitást, az imázst, a személyiséget és a kommunikációt tekinti.

A szervezeti hírnév kiinduló eleme a szervezeti személyiség. Ezt néha a vállalat karakterének is mondják, mert a cég alapvető természetére vonatkozik.

Ezt követi a szervezeti identitás vagy márka: ilyennek akarja a vállalat, hogy lássák, így mutatja magát a belső és a külső partnereinek; így különbözteti meg és pozicionálja magát egy szervezet más szervezetekhez képest (Albert, Whetten 1985).

A szervezeti imázs azt mutatja, ahogyan különböző csoportok érzékelik, értelmezik a vállalatot, ahogyan a szervezet mutatja magát a külvilág, a nyilvánosság felé, különös tekintettel a vizuális eszközökre (Bromley 2001). Az imázs nem a vállalatnál van, hanem azoknál, akik érzékelik a vállalatot. A stakeholderekben a vállalatról kialakuló képet számos összetevő adja, de alapvetően az értékek, hiedelmek és attitüdök befolyásolják (Fazekas, Harsányi 2000; Nyárády, Szeles 2011).

A szervezeti hírnév kollektív fogalom, amely magában foglalja a stakeholderek véleményét a szervezetről, annak identitásáról, imázsáról. Nagyon fontos szem előtt tartani, hogy egy szervezet hírneve nemcsak a fogyasztók, hanem az összes érintett csoport nézetén alapul.

A szervezeti kommunikáció vagy vállalati kommunikáció teszi lehetővé az előbbi négy építőkocka kapcsolódását. Azt támogatja, hogy a hírnév fejlett és tartós legyen.

\section{Vállalati, szervezeti kommunikáció}

A vállalati kommunikáció iránt a kutatók érdeklődése az 1960-70-es években kezdett kibontakozni a reklám, a piac kutatásával párhuzamosan, ami magával vonta a marketingkommunikáció és a PR önálló kutatási területté válását. Az 1980-as évektől a marketingkommunikáció és a PR közeledéséből megszületett az (integrált) vállalati kommunikáció (Cornelissen 2011). A vállalati kommunikáció a vállalat valamennnyi külső és belső célcsoporttal bármely színtéren folytatott interakciója (Ablonczyné Mihályka, Tompos 2017; Borgulya 2010).

A vállalati kommunikáció Fombrun és van Riel (2004) szerint három fö területre osztható:

- menedzsmentkommunikáció, amely a vállalat vezetésének szintjén zajlik a célcsoportokkal; 
- marketingkommunikáció, amely a termékek, szolgáltatások értékesítését, a márkaismertséget szolgálja;

- szervezeti kommunikáció, amely középpontjában a vállalat egésze áll, és magában foglalja a PR-t, a külső kapcsolatokat, a befektetői kapcsolatokat, a vállalat hirdetéseit stb. (Borgulya 2014).

Borgulya (2010) hangsúlyozza, hogy a PR ma kettős értelmezésben használatos, egyrészt a kommunikációmenedzsment része, másrészt a marketingmix, a piaci kommunikáció elemét képezik eszközei. A vállalati kommunikáció és a PR tehát sajátosan összefüggő fogalmak, a különböző PR-orientált, marketingorientált és integrált vállalati kommunikációs, valamint mikro-, mezo- és makroelméleti modellek különböző szemszögből tekintik e sajátos viszonyt.

A jellemző PR-kommunikációs eszközök közül a kutatásunk során imázsfilmeket, honlapokat, imázsbrosúrákat, éves jelentéseket, valamint látogatóközpontokat elemeztünk.

\section{A triple helix modell és gyakorlati megvalósulása Győrben}

A triple helix modell a kormányzat (helyi önkormányzat), a gazdaság és az egyetem együttműködését írja le, a részt vevő szereplők egymás közötti kapcsolatait helyezi előtérbe. Ez a három szereplő a tudásalapú területi fejlődés, a területi tőke alapja egy térségben (Etzkowitz, Leydesdorff 2000; Leydesdorff 2012; Rechnitzer 2016). A modell szereplői közötti kapcsolatok lényege nem azok számszerű alakulása, hanem a létrejövő szinergiák, innováció miatt fontos (Etzkowitz 2003). A triple helix modell kiterjesztése a quadruple helix, melyben az előbbi három elem mellett a társadalmi közeg képviseletében szerepet kap a civil szféra. A quintuple helix ötödik elemként a természeti és épített környezetet is figyelembe veszi (Józsa 2017).

Győrben a triple helix modell a gyakorlatban az 1990-es évektől kezdett megvalósulni, az önkormányzat, a betelepült nagyvállalatok és a munkaerő képzését megfelelően biztosító oktatási intézményrendszer együttműködésével.

Rechnitzer (2016) is egyetért azzal, hogy a modell spontán intézményesülése megtörtént. 2011-ben egy marketingkommunikációs együttműködés keretében deklarálták az együttműködést. „A jövő Győrben épül!” szlogen használata mellett kötelezte el magát három partner: a Széchenyi István Egyetem (oktatás), az Audi Hungaria (gazdaság) és Győr Megyei Jogú Város Önkormányzata (kormányzat). A modell tartalmi megvalósulását Rechnitzer (2016) alapján szemléltetjük (2. ábra).

A három szereplő között számos két- vagy többoldalú együttműködés valósul meg, többek között:

- vállalkozó egyetem: közvélemény-kutatások, lakossági felmérések elvégzése önkormányzati megbízás keretében, az Audi Hungaria reputációkutatásának lefolytatása a vállalat megbízásának keretében, 
2. ábra: Az egyetem, a gazdaság és a város együttműködésének győri modellje The Gyorr-model based on the relationship between university, industry and government

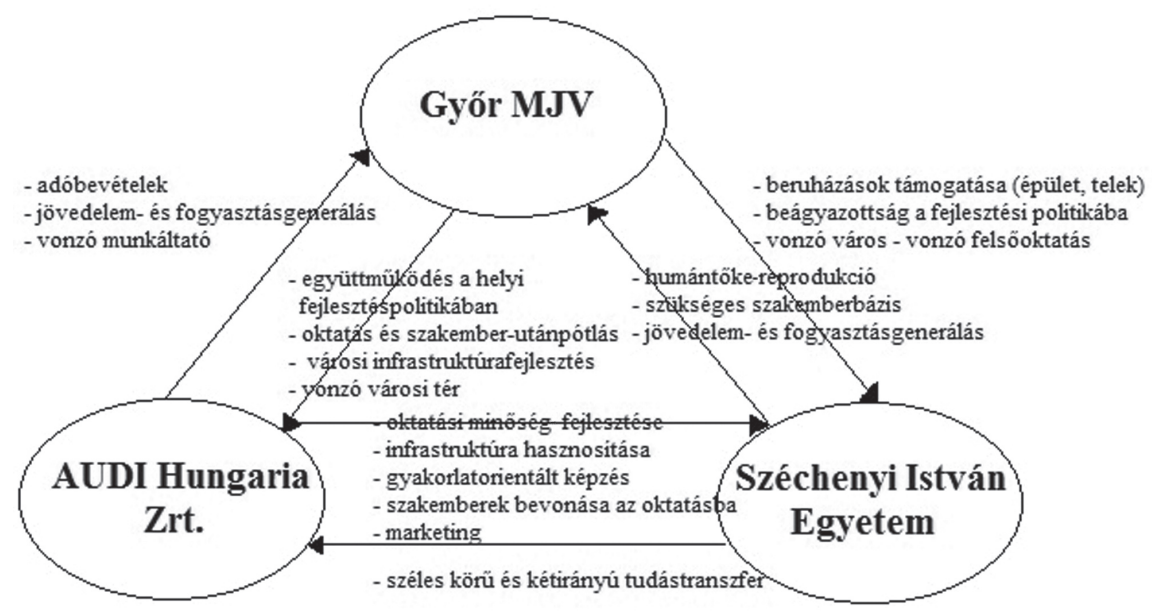

Forrás: Rechnitzer 2016, 245.

- inkubátorház,

- tudományos park (Mobilis Interaktív Kiállítási Központ),

- saját kar alapítása az egyetemen,

- közös megjelenések a három partner által képviselt szektornak megfelelően szakmai vásárokon, kiállításokon: Automotive kiállítás, Educatio kiállítás, Hungexpo Utazás kiállítás,

- közös megjelenés kiadványokban,

- közös logóhasználat (arculati eszközökön, kampányokban stb.),

- győri járműipari életpályamodell.

\section{Hipotézisek és módszerek}

A tanulmányban a következő hipotéziseket vizsgáljuk:

- H1: Győr város (pozitív) hírnevének (ki)alakulásában szerepet játszik az Audi Hungaria.

- H2: A feleknek a kommunikáció és hírnévmenedzsment területén vállalt együttmüködése érzékelhető.

E hipotézisek tesztelésére egyrészt tartalomelemzéssel vizsgálunk 2011 után létrejött vállalati és önkormányzati kommunikációs termékeket. Babbie (2003) alapján a tartalomelemzés a rögzített emberi kommunikációk tanulmányozása. A tartalomelemzésre a PR és a marketingkommunikáció legtöbb eszköze kiválóan megfelel. A tartalomelemzés előnye, hogy hosszabb időszak alatt 
lezajló események elemzését is lehetővé teszi. A tartalomelemzőnek nincs esélye beavatkozásra, így nem befolyásolhatja az elemzés tárgyát (Berelson 1952; Krippendorff 1995).

A vállalati és önkormányzati kommunikációs termékeken belül a 2011-2015 között kiadott PR- és marketingkommunikációs anyagok közül megjelenés és kategória szerint rétegzett mintavétellel az 1. táblázatban szereplő almintákat elemeztük.

1. táblázat: Tartalomelemzéssel megvizsgált PR- és marketingkommunikációs anyagok $P R$ and marketing communication publications examined with content analysis

\begin{tabular}{lll}
\hline \multicolumn{1}{c}{ Elemzési egység } & \multicolumn{1}{c}{ Audi Hungaria } & \multicolumn{1}{c}{ Györ város } \\
\hline Print & Imázsbrosúra 2015 & Imázskiadvány, 2011-2017 \\
Film & Hivatalos imázsfilm & Hivatalos imázsfilm \\
Honlap & www.audi.hu & www.gyor.hu \\
Látogatóközpont & Audi Hungaria látogatóközpont & Látogatóközpont, Tourinform-iroda \\
\hline
\end{tabular}

A látogatóközpontok esetében kvalitatív terepkutatásról, megfigyelésről beszélünk. Ennek során számokká nem egykönnyen redukálható eredmények születnek. E módszer erőssége, hogy a kutató átfogó betekintéshez jut nem csupán a látható környezetbe, hanem részt is tud venni az ott zajló kontextusokban, esetünkben például egy gyárlátogatáson, így bevonódhat a tanulmányozandó világba (Babbie 2003).

Kérdőíves és félig strukturált mélyinterjús felmérést három célcsoport körében végeztünk, a városmarketing-szakirodalom klasszikus három célcsoportos felosztását - befektetők, turisták, városlakók - követve. A primer adatgyűjtés módszere a személyesen lekérdezett félig strukturált interjú volt a befektetői és a turisztikai célcsoport körében. A fóként autóipari beszállító cégek közül 46-nak a képviselője, míg a turisztikai szektorból 61 települést képviselő turisztikai szakértők, egyben győri turisták válaszoltak a kérdésekre. A győri lakosság megkérdezése online formában, a typeform.com internetes kérdő́ivszerkesztő és -kitöltő felület felhasználásával készült 2016. augusztus és szeptember hónapokban, mellyel 340 győri és Győr környéki lakos véleménye vált ismertté.

A szakértői mélyinterjús kutatást alkalmazva az általunk vizsgált szervezetekben a kommunikációért és marketingért felelős szervezeti egységek vezetőinek véleményét tártuk fel 2016-2017 telén. Győr Megyei Jogú Város Polgármesteri Hivatalának városmarketing és programszervezési főosztályvezetője válaszolt az önkormányzati kommunikáció tevékenységére, céljaira, eszközeire vonatkozóan, míg a nagyvállalat részéről az Audi Hungaria Vállalati Kommunikáció és Kormánykapcsolatok Osztályának kommunikációs vezetője volt az interjúalanyunk.

Ahhoz, hogy egységes és ismételt alkalmazásuk lehetővé tegye az adatok összehasonlítását, a félig strukturált interjú formáját választottuk. Az interjúk során a téma szempontjából nagyobb jelentőségű kérdéseket és válaszokat kódoltuk (Seidman 2002). 


\section{Az empirikus vizsgálatok eredményei}

A primer kutatás előtt a Győr város társadalmáról rendelkezésre álló, főleg helyi kutatásokat (Csizmadia 2008; Honvári 2014; Páthy 2014; Rechnitzer 2016; Rechnitzer, Tamándl 2014) szintetizáltuk.

2. táblázat: Az Audi Hungaria és Győr város összefonódása közös projekteken keresztül Cooperation of the Audi Hungaria and the city of Györ through common projects

\begin{tabular}{|c|c|c|}
\hline Az együttmüködés alanya & Audi Hungaria & Györ város \\
\hline \multicolumn{3}{|l|}{ A kultúra szponzorálása } \\
\hline Győri Balett & $\begin{array}{l}\text { Az intézmény fötámogatója } \\
\text { (anyagi támogatás + autó) }\end{array}$ & $\begin{array}{l}\text { A kulturális intézmény fenntar- } \\
\text { tója }\end{array}$ \\
\hline Győri Filharmonikus Zenekar & $\begin{array}{l}\text { Az intézmény támogatója } \\
\text { (anyagi támogatás + autó) }\end{array}$ & $\begin{array}{l}\text { A kulturális intézmény fenntar- } \\
\text { tója }\end{array}$ \\
\hline $\begin{array}{l}\text { Kulturális események: a Nyár- } \\
\text { záró Koncert főszponzora }\end{array}$ & $\begin{array}{l}\text { A koncert fótámogatója (anyagi } \\
\text { támogatás, kiemelt vizuális } \\
\text { megjelenés) }\end{array}$ & Az esemény főszervezője \\
\hline \multicolumn{3}{|l|}{ A sport szponzorálása } \\
\hline Győri AUDI ETO KC & $\begin{array}{l}\text { Az egyesület névadó főszpon- } \\
\text { zora, elnökségi tagok, erőteljes } \\
\text { megjelenés }\end{array}$ & $\begin{array}{l}\text { Az egyesület másik névadó fö- } \\
\text { szponzora, elnökségi tagok, erő- } \\
\text { teljes megjelenés }\end{array}$ \\
\hline ETO FC Győr tao-támogatása & tao-támogatás & Jelentős fenntartási támogatás \\
\hline $\begin{array}{l}\text { Audi Aréna névadó szponzori } \\
\text { támogatása }\end{array}$ & $\begin{array}{l}\text { Névadó főszponzor } 10 \text { évre kö- } \\
\text { tött szerződés alapján, erőteljes } \\
\text { helyszíni megjelenés }\end{array}$ & Építtető, fenntartó \\
\hline $\begin{array}{l}\text { Barátság Sportpark: kültéri fit- } \\
\text { neszpark }\end{array}$ & Főszponzor & Tulajdonos \\
\hline \multicolumn{3}{|l|}{ Egészségügyi ellátás } \\
\hline $\begin{array}{l}\text { Petz Aladár Megyei Oktató Kór- } \\
\text { ház }\end{array}$ & $\begin{array}{l}\text { Egyszeri anyagi adományok, } \\
\text { autó }\end{array}$ & Városi támogatások \\
\hline Háziorvosi szolgálat & Autó & Fenntartó \\
\hline \multicolumn{3}{|l|}{ A civil szféra adományai } \\
\hline $\begin{array}{l}\text { Gézengúz Alapítvány (többek } \\
\text { között) }\end{array}$ & Egyszeri anyagi adományok & - \\
\hline Önkéntesnap & $\begin{array}{l}\text { A vállalat munkatársainak ter- } \\
\text { mészetbeni, a vállalat anyagi tá- } \\
\text { mogatása }\end{array}$ & - \\
\hline Árvízsegítség & Egyszeri anyagi támogatás & $\begin{array}{l}\text { Önkormányzati intézmények, } \\
\text { szervek feladatkörükben segít- } \\
\text { ség, civil segítség }\end{array}$ \\
\hline \multicolumn{3}{|l|}{ Turisztikai együttmúködés } \\
\hline $\begin{array}{l}\text { Győr-kártya, látogatóközpontok } \\
\text { együttműködése }\end{array}$ & $\begin{array}{l}\text { Csatlakozás a turisztikai együtt- } \\
\text { működésekhez }\end{array}$ & $\begin{array}{l}\text { Turisztikai projektek koordiná- } \\
\text { lása, a vállalat bevonásával }\end{array}$ \\
\hline
\end{tabular}




\begin{tabular}{|c|c|c|}
\hline \multicolumn{3}{|c|}{ A városi oktatási rendszerhez való kapcsolódás } \\
\hline $\begin{array}{l}\text { Kéttannyelvű bölcsőde, óvoda, } \\
\text { általános és középiskola }\end{array}$ & $\begin{array}{l}\text { Saját bölcsőde, óvoda és általá- } \\
\text { nos, valamint középiskola üze- } \\
\text { meltetése alapítványon keresz- } \\
\text { tül }\end{array}$ & $\begin{array}{l}\text { Óvodák fenntartója, a középis- } \\
\text { kolai oktatás és az intézmény- } \\
\text { rendszer támogatója }\end{array}$ \\
\hline Duális képzés & Aktív részvétel & Partneri kapcsolatok elősegítése \\
\hline $\begin{array}{l}\text { Széchenyi István Egyetem: Audi } \\
\text { Hungaria Kar }\end{array}$ & Aktív együttmüködés a SZE-vel & Aktív együttműködés a SZE-vel \\
\hline $\begin{array}{l}\text { Mobilis Interaktív Kiállítási Köz- } \\
\text { pont }\end{array}$ & Szponzoráció & $\begin{array}{l}\text { Tulajdonos, fenntartó a SZE } \\
\text { mellett }\end{array}$ \\
\hline $\begin{array}{l}\text { Győri járműipari életpályamo- } \\
\text { dell }\end{array}$ & Jelentős szereplő & Fenntartó \\
\hline \multicolumn{3}{|l|}{ A rendörség támogatása } \\
\hline Rendőrség & Autó & Jelentős támogatás \\
\hline \multicolumn{3}{|c|}{ Városi nagyesemények támogatása } \\
\hline $\begin{array}{l}\text { EYOF (European Youth Olympic } \\
\text { Festival - 2017) }\end{array}$ & $\begin{array}{l}\text { A rendezvény fötámogatója, } \\
\text { mely az egész nemzetközi mul- } \\
\text { tisportesemény arculatát meg- } \\
\text { határozta, egyben tovább mélyí- } \\
\text { tette a két szereplő kapcsolatát }\end{array}$ & $\begin{array}{l}\text { Rendező város, szervezőbizott- } \\
\text { ság, anyagi források biztosítója } \\
\text { saját költségvetésből, valamint } \\
\text { állami támogatásból }\end{array}$ \\
\hline \multicolumn{3}{|l|}{ Gazdasági együttmüködés } \\
\hline Geotermikus erőmü & Társtulajdonos & Társtulajdonos \\
\hline Péri Nemzetközi Repülőtér & Társtulajdonos & Társtulajdonos \\
\hline \multicolumn{3}{|l|}{ Városarculati együttmüködés } \\
\hline $\begin{array}{l}\text { Kiadványok, honlap, rendezvé- } \\
\text { nyek stb. }\end{array}$ & Egymás kölcsönös megjelenítése & Egymás kölcsönös megjelenítése \\
\hline
\end{tabular}

Forrás: Győr MJV PH és az Audi Hungaria információi alapján saját szerkesztés.

A vállalat a bemutatott háttérinformációk szerint szorosan beágyazódott a város társadalmába, közös projekteken keresztül összefonódik annak sport-, kulturális, gazdasági életével, mindennapjaival. A 2. táblázat a konkrét közös projekteket, kezdeményezéseket szemlélteti, melyeket Győr Megyei Jogú Város Önkormányzata és az Audi Hungaria együttesen valósítanak meg.

\section{Szakértői mélyinterjúk}

A szakértői mélyinterjúk során megkérdezett városi és vállalati kommunikációs vezetők véleménye szerint a vizsgált szereplők kölcsönösen hozzájárulnak az együttes hírnévépítéshez, ezt a szervezeti kommunikáció eszköztárának felhasználásával teszik. Nézeteik szerint mindkét szervezet reputációja egyértelmüen pozitív, és a város megítélésében nagyon fontos szerepet játszik az Audi Hungariáról alkotott vélemény (3. táblázat). 
3. táblázat: A szakértői mélyinterjúkban kapott legfontosabb válaszok összegzése summary of deep interview outcomes

\begin{tabular}{|c|c|c|}
\hline $\begin{array}{c}\text { A mélyinterjúkban érintett } \\
\text { fontosabb területek }\end{array}$ & Audi Hungaria & Győr város \\
\hline Stratégiai célok & $\begin{array}{l}\text { - Prémium kategóriás termékek } \\
\text { gyártása, } \\
\text { - Jelentős munkáltató, } \\
\text { - CSR-tevékenység. }\end{array}$ & $\begin{array}{l}\text { - Élhető város, } \\
\text { - Vonzó turisztikai desztináció, } \\
\text { - Prosperáló gazdasági telep- } \\
\text { hely. }\end{array}$ \\
\hline $\begin{array}{l}\text { Egymás megjelenítése a straté- } \\
\text { giai kommunikációban }\end{array}$ & $\begin{array}{l}\text { - Fontos szerep a városnak, } \\
\text { - Szlogenekben is megnyilvánul, } \\
\text { - Stratégiai kommunikáció esz- } \\
\text { közeiben számos alkalommal. }\end{array}$ & $\begin{array}{l}\text { - Büszkén hangsúlyozza a város } \\
\text { gazdasági erejét, } \\
\text { - Ennek zászlóshajója az Audi } \\
\text { Hungaria. }\end{array}$ \\
\hline Példák: & $\begin{array}{l}\text { - CSR, } \\
\text { - Írott és online kommunikáció, } \\
\text { - Közös szlogen, } \\
\text { - Rendezvények. }\end{array}$ & $\begin{array}{l}\text { - CSR, } \\
\text { - Írott és online kommunikáció, } \\
\text { - Közös szlogen, } \\
\text { - Rendezvények. }\end{array}$ \\
\hline $\begin{array}{l}\text { Felhívják-e a látogatók figyel- } \\
\text { mét a gyár/város felkeresésére? }\end{array}$ & $\begin{array}{l}\text { - A honlapon, } \\
\text { - A látogatóközpontban szemé- } \\
\text { lyes ajánlással. }\end{array}$ & $\begin{array}{l}\text { - A látogatóközpontban, } \\
\text { - Kiadványokban (pl. leporelló, } \\
\text { Győr-mappa), } \\
\text { - A honlapon. }\end{array}$ \\
\hline $\begin{array}{l}\text { A látogatóközpont hozzájárulása } \\
\text { a város turizmusához }\end{array}$ & $\begin{array}{l}\text { - Addicionális nevezetesség, } \\
\text { programlehetőség }\end{array}$ & - Turisztikai kínálati elem \\
\hline $\begin{array}{l}\text { Szervezeti színtű és munkaközi } \\
\text { együttmüködés }\end{array}$ & - Kiváló & - Kiváló \\
\hline
\end{tabular}

\section{Kérdőives felmérés}

A turisták, a turisztikai szakemberek Győrrel kapcsolatos asszociációiban egyértelmüen az Audi Hungaria volt a domináns: a megkérdezettek többsége az első három között említette az Audit. A Győrrel azonosított híres emberek, látványosságok, intézmények között is megkérdőjelezhetetlennek bizonyult az Audi Hungaria vezető pozíciója (4. táblázat) (Jakab 2015; Jakab, Konczosné 2016c).

A befektetői szektor megkérdezett képviselőinek Likert-skálán felvett állításai szerint is szerepet játszik a város megítélésében a vállalatról alkotott kép. A kölcsönhatás fordított irányban szintén fennáll a többség véleménye szerint, bár kevésbé egyértelműen (Jakab, Konczosné 2016a, 2016b).

A lakossági kutatás válaszadóinak $(\mathrm{N}=340, \mathrm{n}=327)$ döntő többsége (94,5\%) szerint az Audi Hungaria hírneve hatással van Győr megítélésére, és fordított irányban is ugyanennyien vélekednek így. A Győr pozitív megítélésével egyetértők úgy vélik, hogy a város megítélésében szerepet játszik az Audi Hungariáról alkotott vélemény (5. táblázat). 
4. táblázat: A szereplők hírnevének és azok kölcsönhatásának megítélése Assessment of the actors' reputation and their interaction

\begin{tabular}{lcccc}
\hline \multicolumn{1}{c}{ Értékelés } & $\begin{array}{c}\text { Az Audi Hungaria } \\
\text { hírneve pozitiv }\end{array}$ & $\begin{array}{c}\text { Györ város megitélése } \\
\text { pozitiv }\end{array}$ & $\begin{array}{c}\text { Györ megitélésében } \\
\text { szerepet játszik az } \\
\text { Audi Hungariáról al- } \\
\text { kotott vélemény }\end{array}$ & $\begin{array}{c}\text { Az Audi Hungaria } \\
\text { megitélésében szere- } \\
\text { pet játszik a Györról } \\
\text { alkotott vélemény }\end{array}$ \\
\hline $\begin{array}{l}1-\text { egyáltalán } \\
\text { nem ért egyet }\end{array}$ & 0,0 & 0,0 & 6,5 & 12,5 \\
\hline 2 & 0,0 & 3,1 & 2,8 & 7,3 \\
\hline 3 & 12,7 & 12,1 & 21,9 & 37,4 \\
\hline 4 & 35,8 & 33,3 & 37,5 & 27,2 \\
\hline $\begin{array}{l}5-\text { teljes mér- } \\
\text { tékben egyetért }\end{array}$ & 51,5 & 51,5 & 30,3 & 15,6 \\
\hline Összesen & $n=61$ & $n=60$ & $n=58$ & $n=58$ \\
\hline
\end{tabular}

Forrás: turisztikai kérdőives lekérdezés alapján saját szerkesztés.

5. táblázat: Összefüggés Győr pozitív megítélése és az Audi Hungariának a város megítélésében játszott szerepe között Cross-table of Györ city's and Audi Hungaria's positive reputation

\begin{tabular}{|c|c|c|c|c|c|c|c|}
\hline & & \multicolumn{6}{|c|}{$\begin{array}{c}\text { Györ város megítélésében szerepet játszik az Audi Hungariáról alkotott } \\
\text { vélemény }\end{array}$} \\
\hline & & $\begin{array}{c}\text { Egyáltalán } \\
\text { nem ért } \\
\text { egyet }\end{array}$ & 2 & 3 & 4 & $\begin{array}{c}\text { Teljes mér- } \\
\text { tékben } \\
\text { egyetért }\end{array}$ & Összesen \\
\hline \multirow[t]{5}{*}{$\begin{array}{l}\text { Győr pozitív } \\
\text { megítélése }\end{array}$} & $\begin{array}{l}\text { Egyáltalán nem } \\
\text { ért egyet }\end{array}$ & 1 & 0 & 0 & 0 & 0 & 1 \\
\hline & 3 & 0 & 1 & 1 & 2 & 3 & 7 \\
\hline & 4 & 6 & 6 & 22 & 67 & 27 & 128 \\
\hline & $\begin{array}{l}\text { Teljes mérték- } \\
\text { ben egyetért }\end{array}$ & 7 & 3 & 26 & 63 & 89 & 188 \\
\hline & Összesen & 14 & 10 & 49 & 132 & 119 & 324 \\
\hline
\end{tabular}

Forrás: lakossági lekérdezés eredményei alapján saját szerkesztés.

\section{A kommunikációs eszközök tartalomelemzése}

A mintába kiválasztott print eszközök közül a győri imázskiadvány a város sokszínűségét, hírnevének markáns elemeit mutatja be, melyben az innováció, a gazdaság nevesített, kiemelt képviselője az Audi Hungaria. A vállalatról, termékeiről készült képek illusztrációként is megjelennek. A vállalati imázsbrosúra, mely korábban éves jelentésként a cég eredményeire is koncentrált, 
2015-től a számszerủ adatok háttérbe szorításával a vállalatot helyezi el a társadalomban, bepillantást nyújtva az adott év történéseibe. Mindkét írásos anyag olvasásakor egyértelmü utalásokat, kapcsolatokat fedezhet fel az olvasó a város és a vállalat között, ami erősíti hírnévbeli kapcsolatukat.

A vizsgált szereplők imázsfilmjei ugyanazon cég termékei, ami magyarázza a hasonló stílus és képi megjelenítések alkalmazását. A vállalati film szinte felében a társadalmi felelősségvállalás jegyében támogatott győri intézményeket, valamint győri és helyi emberekről készült színes, kellemes hangulatú jeleneteket láthatunk, ami bizonyítja, a cég otthon érzi magát Győrben, szervesen beágyazott annak társadalmába. Győr város imázsfilmje, ahogyan az imázskiadvány is, a város sokszínűségét hivatott megjeleníteni, melynek a gazdaság, az ipar is része. A filmben az Audi Hungaria mint a város gazdaságának vezető vállalata szerepel. Megállapíthatjuk, hogy a szervezeti kommunikáció e szegmensében is intenzív, a stakeholderek számára egyértelmű a kapcsolat a két szereplő között.

A mintába választott honlapok a www.audi.hu, valamint a www.gyor.hu. Mindkét felületen találunk releváns tartalmat a másik szervezetről. A vállalat gazdag szabadidős lehetőségeket kínáló városként, kirándulócélpontként utal Győrre, a turisztikai információkat a gyárlátogatást tervező vendégeik, egyben fontos stakeholdereik tájékoztatására szerepelteti a honlapon. Emellett számos helyen, főként az oldalra feltöltött hírekben érezhető a szoros kapcsolat a város és a vállalat között. A www.gyor.hu felületén két helyen, a turistáknak, látogatóknak szánt információk között fedezhető fel információ az Audi Hungaria látogatóközpontjáról, emellett a város gazdaságát, az innovációt bemutató aloldal leírásában az imázskiadvány szövege szerepel, melyben a négykarikás gyár képviseli nevesítve a járműipart. A két szereplő hivatalos online platformján is számos egymásra hivatkozás tanúskodik az intenzív kapcsolatról.

A várost vagy a vállalatot személyesen felkeresők is tapasztalhatják az egymásra utalásokat, hiszen mind a belvárosi turisztikai látogatóközpontban, mind az Audi Hungaria látogatóközpontjában kézzel fogható a két szereplő összefonódása. A gyárlátogatásra érkezőket nemcsak a kihelyezett prospektusok vagy a vezetés nyitányaként lejátszott audis imázsfilm ösztönzi a város turisztikai szépségeinek felfedezésére, hanem a látogatóközpont dolgozói is ajánlják Győr behatóbb megismerését. A városi látogatóközpontba információs céllal föként belföldi és külföldi turisták érkeznek, akik megtekintik a városról készült interaktív kiállítást, melyben az innovációfalon a városi gazdaság képviselőjeként az Audi Hungariáról láthatnak információkat. Emellett a Tourinform-irodában érdeklődhetnek a gyárlátogatás felől, továbbá a földszinti shopban audis ajándéktárgyak értékesítése is folyik. 


\section{Következtetések és összegzés}

A kutatás a triple helix modell két szereplöjét, a várost és a vállalatot, kettejük együttműködését elemezte. A hírnévépítés folyamatát tanulmányozva nem az egyes szereplők hírnevének meghatározása állt kutatásunk középpontjában, hanem annak vizsgálata, hogy a szervezeti kommunikáció segítségével hogyan támogatják egymást a felek a hírnévmenedzsmentben, elősegítve ezzel egy közös pozitív hírnév kialakulását, ami Győr város mint lakóhely, mint turisztikai desztináció és mint telephely népszerűségét és területi tőkéjét növeli.

Az előzetes kutatás során elemzett városi és vállalati források szerint Győr város hírneve pozitív, és ennek kialakulásában a kutatás során kapott eredményekből - lakossági, turisztikai, befektetői stakeholderi lekérdezés, valamint szakértői mélyinterjúk - arra következtethetünk, hogy ennek (ki)alakulásában szerepet játszik az Audi Hungaria. Ezért a H1 hipotézist igazoltnak tekintjük.

A lefolytatott vizsgálat eredményeit áttekintve arra a következtetésre juthatunk, hogy mind Győr város, mind az Audi Hungaria tudatosan folytat szervezeti kommunikációs tevékenységet hírneve alakításában; mindkét fél tudatosan törekszik a másik megjelenítésére, tervszerűen együttműködik a két szervezet; ennek eredményeit a stakeholderek is érzékelik. Az Audi Hungaria és Győr város között létrejött marketingkommunikációs együttműködés, „A jövő Győrben épül!” jegyében kölcsönönösen és tudatosan törekednek a partnert megjeleníteni, a kooperáció tartalmas. A kommunikációs és marketingeszközök tartalomelemzésének eredményeiből az a fó következtetés vonható le, hogy az Audi Hungaria és Győr város vállalt együttműködése egyértelműen érzékelhetö, így a H2-es hipotézist is elfogadjuk.

A területi tőke vizsgálata a városok, régiók fejlődése, ennek tudatos útkeresése szempontjából kiemelten fontos. A kutatás lehetséges folytatásaként a triple helix modell harmadik tényezőjével, az akadémiai szféra képviselőjével, Győr esetében a Széchenyi István Egyetem bekapcsolásával lehet tovább vizsgálni a hatásmodellt. Magyarország Győrhöz hasonló vidéki nagyvárosaiban, innovációs, oktatási és gazdasági központjaiban a közelmúltban születtek tanulmányok az egyetem és a vállalatok kapcsolatáról marketingkommunikációs aspektusban: a Pécsi Tudományegyetemen (Deés 2011), valamint a Szegedi Tudományegyetemen (Imreh-Tóth 2014). A kutatás további kiterjesztésére a quadruple helix modell ad lehetőséget.

\section{Irodalom}

Ablonczyné Mihályka L., Tompos A. (2017): Vállalati belső kommunikáció vizsgálata: esettanulmányok Győr-Moson-Sopron megyéből. In: Borgulya Á., Konczosné Szombathelyi M. (szerk.): Vállalati kommunikációmenedzsment: tanulmánykötet. L'Harmattan Kiadó, Károli Gáspár Református Egyetem, Budapest, 67-78. 
Albert, S., Whetten, D. (1985): Organizational identity. In: Staw, B. M. (ed.): Research in organizational behavior. JAI Press, Greenwich, 263-295.

Babbie, E. (2003): A társadalomtudományi kutatás módszertana. Balassi Kiadó, Budapest

Berelson, B. (1952): Content analysis. New York, Free Press

Borgulya Istvánné Vető Á. Á. (2010): Kommunikációmenedzsment a vállalati értékteremtésben. Akadémiai Kiadó, Budapest

Borgulya Istvánné Vető Á. Á. (2014): Kulturális távolságok. Typotex Kiadó, Budapest

Bromley, D. B. (2001): Relationship between personal and corporate reputation. European Journal of Marketing, 3-4., 316-334. http://doi.org/ff3bqv

Cornelissen, J. (2011): Corporate communication: A guide to theory and practice. Sage, London

Csizmadia Z. (2008): Az AUDI Hungaria Motor Kft. Győr város gazdasági és társadalmi életében játszott szerepének megitélése. Kutatási jelentés. Kézirat, MTA RKK NYUTI, SZE, Győr

Deés Sz. (2011): Egyetemi tudománymarketing. A harmadik generációs egyetem szemlélete és kommunikációja. Doktori értekezés. Pécsi Tudományegyetem, Pécs. http://ktk.pte.hu/sites/default/files/ mellekletek/2014/05/Dees\%20Szilvia_disszertacio.pdf (Letöltés: 2017. március 2.)

Enyedi Gy. (1995): Városverseny, várospolitika, városmarketing. Tér és Társadalom, 1-2., 1-3.

Etzkowitz, H. (2003): Innovation in innovation: the triple helix of university-industry-government relations. Social Science Information, 3., 293-337. http://doi.org/bqkmct

Etzkowitz, H., Leydesdorff, L. (2000): The dynamics of innovation: from national systems and „mode 2" to a triple helix of university-industry-government relations. Research Policy, 2., 109-123. http://doi.org/ckvg76

Fazekas I., Harsányi D. (2000): Marketingkommunikáció. Szókratész Külgazdasági Akadémiai Kiadó, Budapest

Fombrun, C. J. (1996): Reputation: Realizing the value from the corporate image. Harvard Business School Press, Boston

Fombrun, C. J., Van Riel, C. B. M. (2004): Fame and fortune. How successful companies build winning reputations. Pearson, Upper Saddle River, Oxford

Honvári J. (szerk.) (2014): Győr fejlődésének mozgatórugói. Universitas-Győr Nonprofit Kft., Győr

Imreh-Tóth M. (2014): Egyetemek vállalkozásoktatásának lehetséges szerepe a vállalkozóvá válás elősegítésében. Doktori értekezés. Szegedi Tudományegyetem, Szeged. http://doktori.bibl. u-szeged.hu/2219/1/Disszertacio_ITM.pdf (Letöltés: 2017. március 2.)

Jakab P. (2014): Győr, városmarketing a gyakorlatban. In: Tózsa I. (szerk.): Turizmus és településmarketing. Budapesti Corvinus Egyetem Gazdaságföldrajz és Jövőkutatás Tanszék, Budapest, 159-168.

Jakab P. (2015): Die Auswirkung der AHM auf den Tourismus von Györ. XIX. Apáczai-napok Nemzetközi Tudományos Konferencia, Győr, 2015. október 21-22.

Jakab P. (2016a): City and company reputation in a tourism point of view. Management of Organizations: Systematic Research, 76., 61-73. http://doi.org/ckc6

Jakab P. (2016b): Kölcsönhatás vizsgálata a városi hírnév és a vállalati hírnév között. In: Juhász Gy., Korcsmáros E., Huszárik E. (szerk.): Korszerü szemlélet a tudományban és az oktatásban. Nemzetközi Tudományos Konferencia - Tanulmánykötet. Selye János Egyetem, Komárno, 139-157.

Jakab P., Konczosné Szombathelyi M. (2016a): Hatásvizsgálat a városi hírnév és a vállalati hírnév között: Az Audi Hungaria Motor Kft. hatása Győr város reputációjára. Gradus, 1., 397-403.

Jakab P., Konczosné Szombathelyi M. (2016b): Hatásvizsgálat a városi hírnév és a vállalati hírnév között (Győr városa és az Audi Hungaria Motor Kft. egymásra gyakorolt hatása). In: Lőrincz I. (szerk.): XIX. Apáczai-napok Nemzetközi Tudományos Konferencia. Gondolkodási struktúrák és kreativitás. Tanulmánykötet. Győr, 546-553.

Jakab P., Konczosné Szombathelyi M. (2016c): Kölcsönhatás vizsgálata a városi hírnév és a vállalati hírnév között turisztikai aspektusban. In: Vágány J., Fenyvesi É. (szerk.): Multidiszciplináris kihívások, sokszinü válaszok. On-line tanulmánykötet 2. Budapesti Gazdasági Egyetem, Budapest. 40-56.

Józsa V. (2017): A vállalati beágyazódás helyi szinten három magyar nagyváros példáján. Doktori értekezés. Szent István Egyetem, Gödöllő

Konczosné Szombathelyi M. (2013a): A hírnév értéke, a reputáció mérhetősége. In: Király É. (szerk.): Kiterjesztett marketing. BGF, Budapest, 504-516. 
Konczosné Szombathelyi M. (2013b): A hírnév és menedzselése. In: Tompos A., Ablonczyné Mihályka L. (szerk.): Növekedés és egyensúly. Széchenyi István Egyetem, Győr. 1-11.

Konczosné Szombathelyi M. (2013c): A vállalati hírnév fogalma, menedzsmentje, mérhetősége. Előtanulmány reputációkutatáshoz, kézirat. Győr

Kotler, P., Mindak, W. (1991): Marketing and public relations. In: Harris, T. L. (ed.): The marketer's guide to public relations. Wiley, 41-42.

Krippendorff, K. (1995): A tartalomelemzés módszertanának alapjai. Balassi Kiadó, Budapest

Leydesdorff, L (2012): The triple helix of university-industry-government relations. https://core.ac.uk/ download/pdf/11888706.pdf (Letöltés: 2017. február 21.)

Nyárády G., Szeles P. (2011): Public relations I-II. Perfekt Kiadó, Budapest

Páthy Â. (2014): A társadalmi szervezet belső területi sajátosságai. A győri városrészek és lakóövezetek társadalmi tagozódása. In. Csizmadia Z., Tóth P. (szerk.): Helyi társadalom és intézményrendszer Győrben. Universitas-Győr Nonprofit Kft., Győr. 45-68. (A győri járműiipari körzet, mint a térségi fejlesztés új irányai és eszköze c. kutatás monográfiái; 4.)

Piskóti I. (2012): Régió- és településmarketing. Marketingorientált fejlesztés, márkázás. Akadémiai Kiadó, Budapest

Piskóti I., Dankó L., Schupler, H., Büdy L. (2002): Régió és településmarketing. KJK Kerszöv, Budapest

Rechnitzer J. (2016): A területi tőke a városfejlődésben. A Győr-kód. Dialóg Campus Kiadó, Budapest, Pécs

Rechnitzer J., Tamándl L. (2014): A győri jármüipari körzet, mint a térség új iránya és eszköze. Széchenyi István Egyetem, Győr

Roper, S., Fill, C. (2012): Corporate Reputation. Pearson, Harlow, New York

Seidman, I. (2002): Az interjú mint kvalitatív kutatási módszer. Műszaki Könyvkiadó, Budapest

Whetten, D. (1997): Part II: Where do reputations come from? Theory development and the study of corporate reputation. Corporate Reputation Review, 1., 25-34. http://doi.org/fw5jqq 